\title{
THE ROLE OF CHARISMATIC LEADERSHIP STYLE AND EFFECTIVE BEHAVIOR ON WORK MOTIVATION AND ITS IMPACT ON PERFORMANCE OF PIDIE GOVERNMENT HEALTH OFFICE
}

\author{
*Roni Ahmad, MukhlisYunus and Said Musnadi \\ Management department, Universitas Syiah Kuala, Indonesia \\ http://doi.org/10.35409/IJBMER.2021.3260
}

\begin{abstract}
This study aims to measure the influence of charismatic leadership style and affective behavior on work motivation and its impact on the performance of the Pidie Government Health Office. The population in this study was all civil servants of the Pidie Government Health Office, as many as 1542 people. The sample was determined by the Slovin formula and it providedas many as180respondents. Structural Equation Modeling (SEM) was used as a method to determine the effect of all the variables. From the research results that have been described, hypotheses conclusions can be drawn are: Charismatic leadership style affects Work Motivation, Affective Behavior affects Work Motivation, Charismatic leadership style does not affect Organizational Performance, Affective Behavior affects the Organizational Performance, Work Motivation affects Organizational Performance, Work Motivation fully mediates the influence of Charismatic leadership style on Organizational Performance, and Work Motivation partially mediates the influence of Affective Behavior on Organizational Performance. These findings conclude that an increase in Charismatic leadership style cannot directly impact on increasing organization performance, but at the beginning, it would affect an increase in work motivation and then later would have an impact on increasing organizational performance. Meanwhile, the increase in Affective Behavior is said to be able to increase organizational performance either directly or through its effect on increasing work motivation. This means that this model is proven to be applicable to the Pidie government health office, namely by making improvements in charismatic leadership style and affective behavior, it will systemically affect the increase in work motivation and have an impact on organizational performance. For future researchers, it is hoped that they can develop this tested model by adding other variables such as job satisfaction, work environment, and workload, which are closely related to organizational performance.
\end{abstract}

Keyword: Charismatic leadership style, Affective Behavior, Work Motivation, Organizational Performance.

\section{INTRODUCTION}

Pidie Government Health Office is is a government agency in the Pidie Regency, Indonesia, which administers local government affairs related to public health. The responsibility is carrying out general government tasks and development in the health sector following the 


\section{International Journal of Business Management and Economic Review}

Vol. 4, No. 03; 2021

ISSN: 2581-4664

provisions of laws and regulations.

The policy is formulated around the vision, mission, goals and objectives, and strategic direction. This health development policy also takes into account the commitment of the Pidie Regency Government, in order to measure and improve performance and increase accountability in the health management of the Pidie district. The main performance indicators (IKU) need to be determined because the main performance indicators will be the key in the annual performance plan as the key to identify programs and activities to be implemented in that year.

In this research, Pidie Government Health Office is the object of this research, related to the performance and the measurement by looking at the Main Performance Indicators (IKU) of the department concerned. The performance achievement from the 2019 Pidie Government Health Office LAKIP report shows unsatisfactory results, because it is still below the target. The realization of the $100 \%$ target for health services is only $71 \%$. The number of villages experiencing dengue fever (DHF) Extraordinary Events (KLB), treated malaria patients and treated filariasis cases, villages with UCI have also not reached the target because the realization is only $85 \%$. Meanwhile, for the development of health service standards, only $94 \%$ was realized. Indicator Percentage of office administration realization has also only reached $80 \%$.

The not optimal achievement of targets carried out by this office highly depending on the work motivation of its employees (Osabiya \& Joseph, 2015); (Manzoor, 2012) This is in line with research conducted by (Ritz, 2009) which concludes that there is a close relationship between organizational performance and employee motivation. Work motivation is a form of positive encouragement so that they are encouraged and have more enthusiasm in carrying out their work. The not yet optimal aspect of work motivation in supporting organizational achievement is confirmed from the results of preliminary research conducted using 30 respondents who were randomly assigned to the staff. The survey results obtained show that the mean value of each indicator of work motivation that is perceived by employees is $<3.40$, It concludes that aspects related to work motivation are still considered problematic so that they have an impact on employee performance and organizational performance.

The work motivation factor is strongly influenced by the leadership style, especially the charismatic leadership style. This was also revealed by (Barbuto, 2005); (Shamir, House, \& Arthur, 1993); (Choi, 2006). In their research, they found a positive and significant influence between Charismatic Leadership Style and employee work motivation.

Another factor that affects work motivation is the employee's affective behavior. According to (Cremer, 2006); (Seo, Bartunek, \& Barrett, 2011); (Galletta, Portoghese, \& Battistelli, 2011) Affective behavior is related to attitudes and values. Affective behavior includes behavioral characteristics such as feelings, interests, attitudes, emotions, and values. The characteristics of affective learning outcomes are manifested in various forms of behavior.

The affective field is divided into five levels, namely accept or participate (accept or pay attention), the answer means "active participation", evaluation (evaluation or recognition), organization (organization or organization), characteristics through evaluation. Or a value complex (a value-based characteristic or a value complex).

Many previous studies have examined the factors that influence organizational performance, including the use of motivation variables (Osabiya \& Joseph, 2015); (Ritz, 2009); (Azar \& Shafighi, 2013), charismatic leadership styles (Shea \& Howell, 1999); (E. Wang, Chou, \& Jiang, 2005); (Wilderom, Berg, \& Wiersma, 2012) and employee affective behavior (Cole, Walter, \& 


\section{International Journal of Business Management and Economic Review}

Vol. 4, No. 03; 2021

ISSN: 2581-4664

Bruch, 2008); (Norris-Watts \& Levy, 2004); (Vandenberghe, Bentein, \& Stinglhamber, 2004); (Ramirez-Solis \& Baños-Monroy, 2015) and also charismatic leaderships (Shea \& Howell, 1999); (E. Wang et al., 2005); (Handoyo, 2015), but not many of them have researched the aspects related to charismatic leadership variables. In many studies, the variable leaderships style is seen as the antecedent variable of organizational performance (F.-J. Wang, Chich-Jen, \& MeiLing, 2010), The fact is that organizational performance really depends on how the style of the leader directs and utilizes all available resources to achieve organizational goals.

But in fact, there is something more essential than just exploring the charismatic aspects inherent in a leader in predicting organizational performance, because the impetus is different when discussing the performance aspects of individuals or groups in an organization, even though both have an impact on the achievement of organizational performance. This has been stated by (DeGroot, Kiker, \& Cross, 2000) in their study which used meta-analysis to assess the relationship between charismatic leadership style and leadership effectiveness, as well as its relation to individual and group performance of subordinates and its impact on organizational performance. These results suggested that charismatic leadership is more effective at increasing group performance than at increasing individual performance. Therefore, the authors consider it necessary to further explore how the role of charismatic leadership in raising group performance (group cohesiveness) in addition to individual employee performance.

So from the existing research gap, the authors of this paper will add group cohesiveness aspects as attributes variable charismatic leaderships to predict their role in improving organizational performance. This attribute also serves as the novelty of this research.

\section{LITERATURE REVIEW}

\subsection{Organizational Performance}

Organizational performance is an achievement that reflects organizational success, and the result of the behavior of organizational members. Organizational effectiveness is the amount of work carried out by an organization, organizational achievement means that the effectiveness of an organization can be seen in how far an organization can achieve its goals based on predetermined goals (Surjadi, 2009). According to (Sobandi et al., 2006), organizational effectiveness is what an organization has achieved within a certain period, regarding inputs, outputs, outputs, benefits, and impacts.

Based on the opinion of (Mahmudi, 2013), the factors that affect organizational performance can also be seen from organizational commitment measured from team factors with the support and enthusiasm given by teammates, trust in fellow team members, team member's cohesiveness. Another factor is job satisfaction measured from organizational system factors by looking at work systems, work facilities, or infrastructure provided by the organization, organizational processes, and work culture in the organization. Another factor that affects organizational performance is employee performance, which can be measured from individual employee factors by looking at the knowledge, abilities, and self-confidence possessed by each individual.

The factors that affect organizational performance according to (Mukhlis, Musnadi, \& Ridwan, 2020) are organizational commitment, job satisfaction, and employee performance. There are five bases that can be used as indicators of public sector performance, including:

1.Service; 2.Economy; 3.Efficient; 4.Effectiveness; and 5.Equity. 


\section{International Journal of Business Management and Economic Review}

Vol. 4, No. 03; 2021

ISSN: 2581-4664

\subsection{Work motivation}

Motivation is the willingness to make high-level efforts to achieve organizational goals, driven by individuals. While motivation generally refers to the efforts made to achieve each goal. In this study, what is meant is organizational goals because it focuses on behavior related to workrelated organizational goals. There are three key elements in this definition: effort, organizational goals, and needs. (Porter, Bigley, \& Steers, 2003).

According to the Hasibuan motivation theory (Hasibuan, 2016), a person's productivity can be determined by the "mental virus" in him. Mental viruses are mental conditions that encourage a person to achieve maximum results. (Siagan, 2012) added that there are intrinsic factors and extrinsic factors in work motivation, namely:

1.Intrinsic factors: factors that satisfy and come from themselves such as affective behavior and charismatic leadership style.

2.Extrinsic factors: external factors

According to (Mukhlis et al., 2020) the factors that influence work motivation are employee empowerment, talent, work environment, and career development.

Work Motivation Indicators According to (Azar \& Shafighi, 2013) are as follows:

1.Physical Needs

2.Needs a sense of security \& safety

3.Social needs

4.Need for appreciation

5.Needs self-manifestation

\subsection{Leadership Style (Charismatic)}

In this study, the term charismatic leadership style is equated with a leadership style, because the theoretical basis is a leadership style. However, the elaboration of the indicators and analysis will be more specific and will elaborate on the charismatic leadership character. (Gopal \& Chowdhury, 2014) stated that: "Leadership style is a way of influencing the behavior of subordinates which aims to encourage work passion, job satisfaction, and employee productivity in order to achieve maximum organizational goals." Meanwhile, (Basna, 2016) stated that: "The leadership style represents the philosophy, skills, and attitudes of a leader in politics. Leadership style is a pattern of behavior designed to integrate organizational goals with individual goals to achieve certain goals ". Practically there are five main functions of leadership stated by (Handoyo, 2015), namely:1.Instruction Function; 2.Consulting Function; 3.Participatory function; 4.Delegation function, and; 5.Control function. Indicators of Charismatic Leadership Style according to (Wilderom et al., 2012) are as follows;

1.Communication; Maturity; They have very strong personalities. They use their wisdom and knowledge they accumulated over the years of life and business experience. They behave maturely and responsibly at all times.

2.Humility; They value every employee and have the ability to listen to them. Charismatic leaders can convince employees of the value they bring to the organization. They inspire great loyalty from their employees.

3.Compassion; successful charismatic leaders are also compassionate. Compassion, integrity, honesty are also qualities that successful charismatic leaders exhibit.

4.Substance; Charisms can exist without substance, but only for a very short time. Fancy 


\section{International Journal of Business Management and Economic Review}

Vol. 4, No. 03; 2021

ISSN: 2581-4664

behavior might grab people's attention, but they'll also want something substantial. A charismatic leader does not just talk, he does something.

5.Confidence; charismatic leaders are genuinely self-assured. They understand themselves well and don't try to be someone else.

\subsection{Affective Behavior}

Affective behavior is a behavior related to attitudes and values. Affective abilities are part of learning outcomes and play an important role. Affective learning is important to encourage the development of values, ethics, aesthetics, and feelings in employee learning environments. Learning success in the cognitive and psychomotor fields is largely determined by a person's affective state. People who are interested in learning and have a positive attitude towards lessons will enjoy studying these subjects so that they are expected to achieve optimal learning outcomes.

According to (Cole et al., 2008), the number of these affective assessment indicators can vary, but at least they must meet the indicator requirements, as follows:

1.The individual's attitude towards himself during the learning process at work

2.Individual attitudes concerning their superiors during the learning process at work

3.Individual attitudes in relationships with colleagues during the learning process at work

4.Individual attitudes concerning their environment during the learning process at work

5.Individual responses to learning materials obtained at work.

\subsection{Research Hypothesis}

Based on the literature and facts above, several hypotheses were determined to be tested in this research, namely :

H1 :Charismatic leadership style affects Work Motivation.

$\mathrm{H} 2$ : Affective Behavior affects Work Motivation

H3 :Charismatic leadership styledoes not affect Organizational Performance

H4 : Affective Behavior affects the Organizational Performance

H5 : Work Motivation affects Organizational Performance

H6 : Work Motivation mediates the effect of Charismatic leadership style on Organizational Performance

H7 : Work Motivation mediates the effect of Affective Behavior on Organizational Performance

\section{RESEARCH METHOD}

\subsection{Population and Sample}

The population in this study was all Civil Servants of the PidieGovernment Health Office, as many as 1542 people. The determination of the minimum number of sampleused the Slovin formula (Umar, 2008)and it provided 180 respondents as a sample.

\subsection{Data Collection Techniques}

The data required/collected for analysis purposes included primary data and secondary data. The data used in this study were:

1.Primary data collected directly through a questionnaire consisting of question items distributed to Civil Servants of the PidieGovernment Health Office. 
International Journal of Business Management and Economic Review

Vol. 4, No. 03; 2021

ISSN: 2581-4664

2.Secondary data, obtained from the PidieGovernment Health Office.

\subsection{Data Analysis Method}

The data analyzedusing The Structural Equation Modeling (SEM) method,after the Confirmatory Factor Analysis (CFA) was done.SEMwas used to test the theoretical model, which was based on a goodness-of-fit measure (F. Hair Jr, Sarstedt, Hopkins, \& G. Kuppelwieser, 2014). The research model is as shown below.

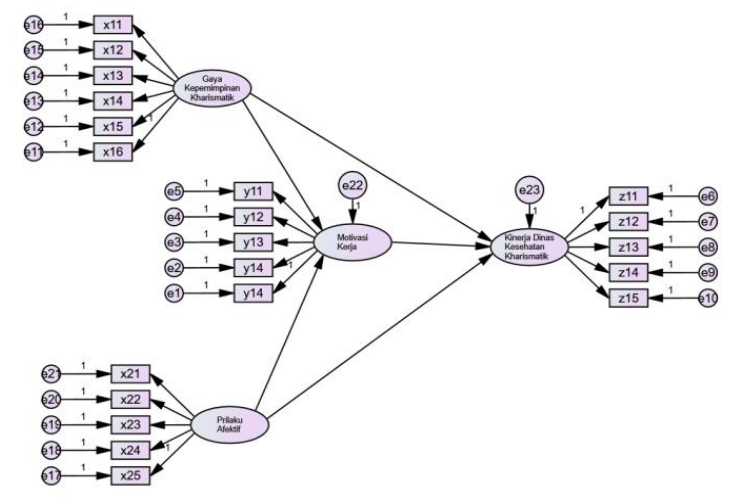

Figure 1. Research Model

As we see infigure 1 above, mathematically the causality relationship between the constructs in the study can be stated as follows:

$\eta_{1}=\gamma 1.1 \xi 1+\gamma 1.2 \xi 2+\zeta 1$

$\eta_{2}=\gamma 2.1 \xi 1+\gamma 2.2 \xi 2+\beta 21 \eta_{1}+\zeta 2$

\section{RESULT AND DISCUSSION}

\subsection{Research result}

Testing using SEM analysis was carried out in two stages, wherein the first stage, using the CFA technique, and the second stage, using the Full SEM technique (Ghozali, 2017).

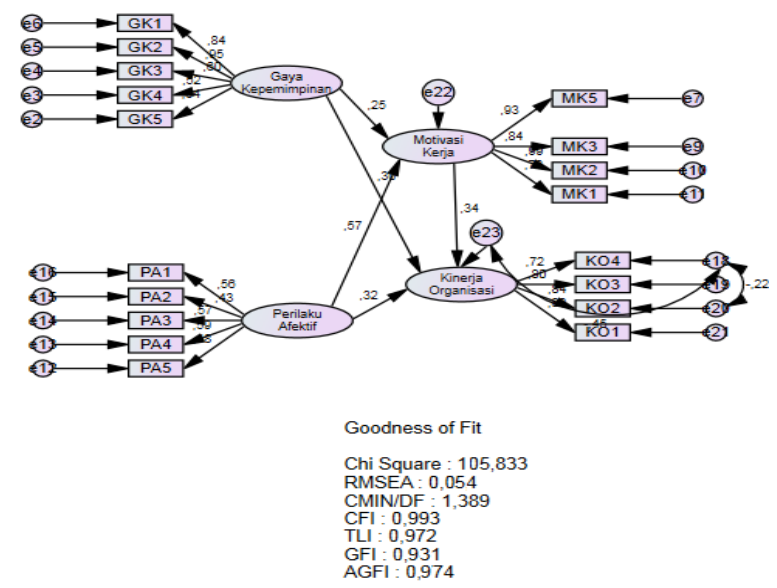




\section{International Journal of Business Management and Economic Review}

Vol. 4, No. 03; 2021

ISSN: 2581-4664

Figure 2. SEM Test Result

This hypothesis testing is done by analyzing the Critical Ratio (CR) value and the probability $(\mathrm{P})$ value, compared to the required statistical limits, which are above 1.96 for the $\mathrm{CR}$ value and below 0.05 for the P-value.

Table 1. Hypothesis Test Result

\begin{tabular}{|c|c|c|c|c|c|}
\hline Effect & Estimate & S.E. & C.R. & $P$ & $\begin{array}{c}\text { R- } \\
\text { Square }\end{array}$ \\
\hline Work Motivation $\leftarrow$ Leadership Style & 0,246 & 0,106 & 3,233 & 0,000 & \\
\hline Work Motivation $\leftarrow$ Affective Behavior & 0,568 & 0,109 & 4,335 & 0.000 & 0,389 \\
\hline Organizational Performance $\leftarrow$ Leadership Style & 0,298 & 0,072 & 3,839 & 0,188 & \\
\hline Organizational Performance $\leftarrow$ Affective Behavior & 0,318 & 0,161 & 2,729 & 1,001 & 0,481 \\
\hline Organizational Performance $\leftarrow$ Work Motivation & 0,342 & 0,064 & 3,609 & 0,000 & \\
\hline
\end{tabular}

Source: Data processed (2020)

Based on the results of SEM analysis in Table 1, the statistical equations (1) and (2) can be formulated:

Work Motivation $=0.246$ Charismatic leadership style +0.568 Affective Behavior

Organizational Performance $=0.298$ Charismatic leadership style +0.318 Affective Behavior + 0.342 Work Motivation

Based on Table 1, it is obtained that the R square value for the effect of Charismatic leadership style and Affective Behavior on Work Motivation is 0.389. This shows that the charismatic leadership style and affective behavior can affect the work motivation variable by $38.9 \%$, while the remaining $61.6 \%$ is influenced by other variables outside Charismatic leadership style and Affective Behavior.

The value of $\mathrm{R}$ square for the effect of Charismatic leadership style, Affective Behavior, and Work Motivation on Organizational Performance is 0.481 . This shows that the variable of Charismatic leadership style, Affective Behavior, and Work Motivation can affect the Organizational Performance variable by $48.1 \%$, while the remaining $51.9 \%$ is influenced by other variables outside Charismatic leadership style, Affective Behavior, and Work Motivation.

\section{H1 :The Effect of Charismatic leadership style on Work Motivation}

The effect of Charismatic leadership style on Work Motivation obtained a CR value of 3.233 with a significance level of 0.001 . It concludes that the Charismatic leadership style can affect Work Motivation. The amount of effect of Charismatic leadership style on Work Motivation is 0.246 or $24.6 \%$. This indicates that the better the charismatic leadership style will have a positive and real effect on increasing employee work motivation.

\section{H2 :The Effect of Affective Behavior on Work Motivation}

The effect of Affective Behavior on Work Motivation obtained a CR value of 4,335 with a significance level of 0,000. It concludes that Affective Behavior can affect increasing Work 


\section{International Journal of Business Management and Economic Review}

Vol. 4, No. 03; 2021

ISSN: 2581-4664

Motivation. The coefficient of the effect of affective behavior on work motivation is 0.568 or $56.8 \%$. This indicates that the higher the level of affective behavior, the higher the employee's work motivation.

\section{H3 :The Effect of Charismatic leadership style on Organizational Performance}

The effect of Charismatic leadership style on Organizational Performance obtained a CR value of 3.839 with a significance level of 0.000 . Thus, It concludes that the Charismatic leadership style can affect Organizational Performance. The amount of effect of Charismatic leadership style on Organizational Performance is 0.298 or $29.8 \%$. This indicates that the better the Charismatic leadership style will have a positive and real effect on increasing Organizational Performance.

\section{H4 :The Effect of Affective Behavior on Organizational Performance}

The effect of Affective Behavior on Organizational Performance obtained a CR value of 2.729 with a significance level of 0.006 . Thus, It concludes that Affective Behavior can affect Organizational Performance. The coefficient of the effect of Affective Behavior on Organizational Performance is 0.318 or $31.8 \%$. This indicates that the higher the level of affective behavior will increase organizational performance.

\section{H5 :The Effectof Work Motivation on Organizational Performance}

The effect of work motivation on the organizational performance obtained a CR value of 3.609 with a significance level of 0.000 . In other words, work motivation can affect organizational performance. The coefficient of the effect of Work Motivation on Organizational Performance is 0.342 or $34.2 \%$. This indicates that the higher work motivation will have a direct effect on increasing organizational performance.

H6 :The Effect of Charismatic leadership style on Organizational Performance through Work Motivation

The mediating effect of the Charismatic leadership style variable on Organizational Performance can be explained as follows.

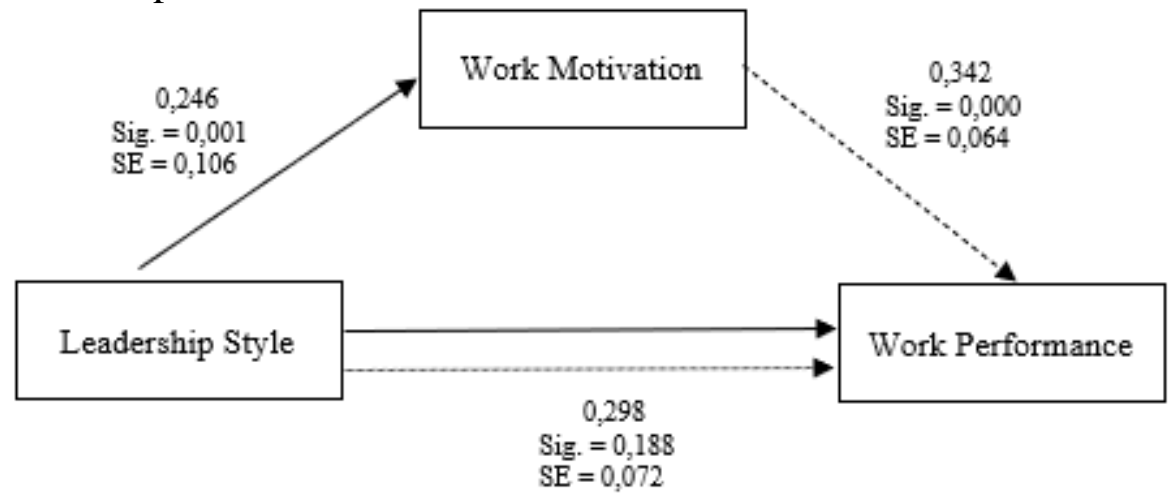

Figure .3 Mediating Effect of H6

From the calculation of the Sobel test, the result is 2.128 and it is significant at $\alpha=0.033$. Thus, Work Motivation acts as a variable that mediates between Charismatic leadership style and 


\section{International Journal of Business Management and Economic Review}

Vol. 4, No. 03; 2021

ISSN: 2581-4664

Organizational Performance. Thus, because work motivation has a significant effect and acts as a mediating variable, charismatic leadership style has a significant effect on organizational performance, so the role of work motivation in mediating the relationship between charismatic leadership style and organizational performance is partially mediating.

In Figure 3, the results of the Sobel value can be seen in Table 2 as follows:

Table 2. Sobel Test Result of H6

\begin{tabular}{|c|c|c|c|c|c|}
\hline & Input: & & Test statistic: & Std. Error: & p-value: \\
\hline$a$ & 0.246 & Sobel test: & 2.12867536 & 0.03952317 & 0.03328113 \\
\hline$b$ & 0.342 & Aroian test: & 2.09799374 & 0.04010117 & 0.0359057 \\
\hline$s_{a}$ & 0.106 & Goodman test: & 2.16074367 & 0.03893659 & 0.03071515 \\
\hline & 0.064 & Reset all & & Calculate & \\
\hline
\end{tabular}

\section{H7 :The Effect of Affective Behavior on Organizational Performance through Work Motivation}

The results showed that testing the mediating effect of the Affective Behavior on Work Motivation can be explained as follows:

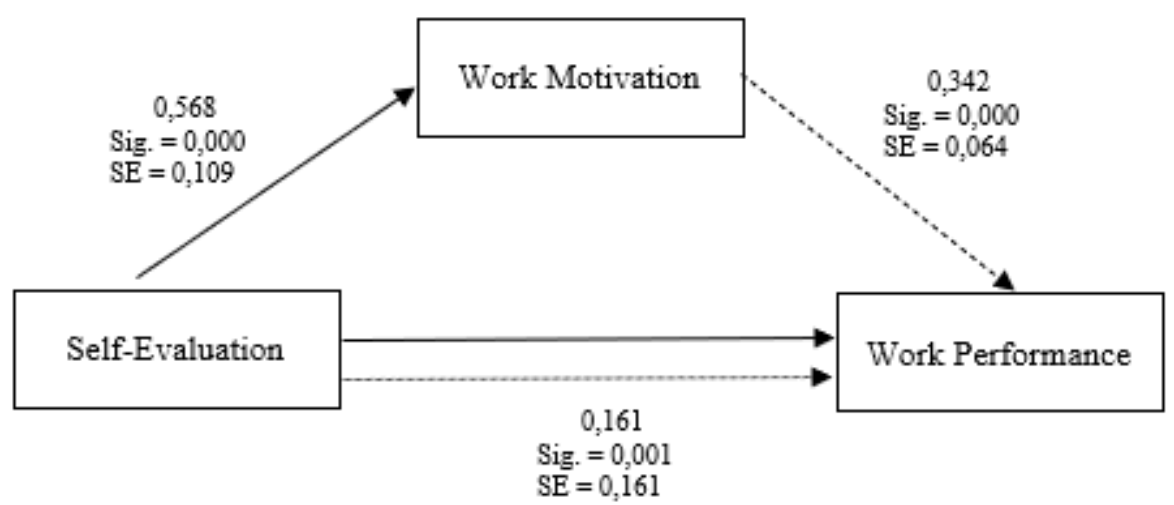

Figure 4. Mediating Effect of H7

From the Sobel test, the result is 3,730 and it is significant at $\alpha=0,000$. Thus, Work Motivation acts as a variable that mediates between Affective Behavior and Organizational Performance. So, because work motivation has a significant effect and acts as a mediating variable, affective behavior has a significant effect on organizational performance, so the role of work motivation in mediating the relationship between affective behavior and organizational performance is partially mediating.

In Figure 4, the results of the Sobel value can be seen in Table 3 as follows: 


\section{International Journal of Business Management and Economic Review}

Vol. 4, No. 03; 2021

ISSN: 2581-4664

Table 3. Sobel Test Result of $\mathbf{H 7}$

\begin{tabular}{|c|c|c|c|c|}
\hline Input: & & Test statistic: & Std. Error: & p-value: \\
\hline$a 0.568$ & Sobel test: & 3.73078564 & 0.05206839 & 0.00019088 \\
\hline$b 0.342$ & Aroian test: & 3.69774596 & 0.05253363 & 0.00021752 \\
\hline$s_{a} 0.109$ & Goodman test: & 3.76472708 & 0.05159896 & 0.00016673 \\
\hline$s_{\mathrm{b}} 0.064$ & Reset all & & Calculate & \\
\hline
\end{tabular}

\section{CONCLUSION}

From the research results that have been described, hypotheses conclusions can be drawn are:Charismatic leadership style affects Work Motivation, Affective Behavior affects Work Motivation, Charismatic leadership styledoes notaffect Organizational Performance, Affective Behavior affects the Organizational Performance, Work Motivation affects Organizational Performance, Work Motivation fully mediates the effect of Charismatic leadership style on Organizational Performance, and Work Motivation partially mediates the effect of Affective Behavior on Organizational Performance. These findings conclude that an increase in Charismatic leadership style cannot directly impact on increasing organization performance, but at the beginning, it would affect an increase in work motivation and then later would have an impact on increasing organizational performance. Meanwhile, the increase in Affective Behavior is said to be able to increase organizational performance either directly or through its effect on increasing work motivation. This means that this model is proven to be applicable to the PidieGovernment health office, namely by making improvements in charismatic leadership style and affective behavior, it will systemically affect the increase in work motivation and have an impact on organizational performance. For future researchers, it is hoped that they can develop this tested model by adding other variables such as job satisfaction, work environment, and workload, which are closely related to organizational performance.

Some suggestions for Pidie Government Health Office based on the research results can be given. For the Charismatic leadership style variable, the lowest indicator is confidence. So this can be a consideration for the organization in improving the leadership confidence so the subordinates could give more respect to the leader. Whereas for the Affective Behavior variable, the lowest indicator obtained is the response to the learning material. So this indicator can be a consideration for organizations in improving learning materials that can better support the implementation of work.

\section{REFERENCE}

Azar, M., \& Shafighi, A. A. (2013). The Effect of Work Motivation on Employees' Job Performance (Case Study: Employees of Isfahan Islamic Revolution Housing Foundation). International Journal of Academic Research in Business and Social Sciences, 3(9), 432-445. https://doi.org/10.6007/IJARBSS/v3-i9/231

Barbuto, J. E. (2005). Motivation and Transactional, Charismatic, and Transformational 


\section{International Journal of Business Management and Economic Review}

Vol. 4, No. $03 ; 2021$

ISSN: 2581-4664

Leadership: A Test of Antecedents. Journal of Leadership \& Organizational Studies, 11(4), 2640. https://doi.org/https://doi.org/10.1177/107179190501100403

Basna, F. (2016). Analisis Gaya Kepemimpinan, Kepuasan Kerja, Komitmen Organisasi dan Kompetensi terhadap Kinerja Pegawai. Jurnal Riset Bisnis Dan Manajemen, 4(3), 319-334.

Choi, J. (2006). A Motivational Theory of Charismatic Leadership: Envisioning, Empathy, and Empowerment. Journal of Leadership \& Organizational Studies, 13(1), 24-43. https://doi.org/https://doi.org/10.1177/10717919070130010501

Cole, M. S., Walter, F., \& Bruch, H. (2008). Affective mechanisms linking dysfunctional behavior to performance in work teams: a moderated mediation study. Journal of Applied Psychology, 93(5), 945-958. https://doi.org/10.1037/0021-9010.93.5.945

Cremer, D. De. (2006). Affective and motivational consequences of leader self-sacrifice: The moderating effect of autocratic leadership. The Leadership Quarterly, 17(1), 79-93. https://doi.org/https://doi.org/10.1016/j.leaqua.2005.10.005

DeGroot, T., Kiker, D. S., \& Cross, T. C. (2000). A Meta-Analysis to Review Organizational Outcomes Related to Charismatic Leadership. Canadian Journal of Administrative Sciences, 17(4), 356-372. https://doi.org/10.1111/j.1936-4490.2000.tb00234.x

F. Hair Jr, J., Sarstedt, M., Hopkins, L., \& G. Kuppelwieser, V. (2014). Partial least squaresstructural equation modeling (PLS-SEM) An emerging tool in business research. European Business Review, 26(2), 106-121.

Galletta, M., Portoghese, I., \& Battistelli, A. (2011). Intrinsic Motivation, Job Autonomy and Turnover Intention in the Italian Healthcare: The mediating role of Affective Commitment. Journal of Management Research, 3(2), 1-19. https://doi.org/10.5296/jmr.v3i2.61

Ghozali, I. (2017). Model Persamaan Struktural, Konsep dan Aplikasi dengan Program AMOS 24 Update Bayesian SEM (Edisi 7). Semarang: Badan Penerbit Universitas Diponegoro.

Gopal, R., \& Chowdhury, R. G. (2014). Leadership Styles And Employee Motivation: An Empirical Investigation In A Leading Oil Company In India. IMPACT: International Journal of Research in Business Managemen, 2(5), 1-10.

Handoyo, L. N. (2015). The Influence Of Leadership Styles On Employee's Performance Through Work Motivation (An Organizational Study At Four Hotels In Malang). Jurnal Administrasi Bisnis, 22(1), 1-7.

Hasibuan, M. S. (2016). Buku Manajemen Sumber Daya Manusia (Revisi). Jakarta: Bumi Aksara.

Mahmudi, M. (2013). Manajemen Kinerja Sektor Publik. Yogyakarta: UPP-STIM YKPN.

Manzoor, Q.-A. (2012). Impact of Employees Motivation on Organizational Effectiveness. Business Management and Strategy, 3(1), 1-12. https://doi.org/https://doi.org/10.5296/bms.v3i1.904

Mukhlis, Musnadi, S., \& Ridwan, N. (2020). The Effect of Organizational Commitment and Job Satisfaction on Employee Performance and its Implication on the Performance of PT. PLN 


\section{International Journal of Business Management and Economic Review}

Vol. 4, No. 03; 2021

ISSN: 2581-4664

(Persero) Banda Aceh. International Journal of Scientific and Management Research, 3(3), 2334.

Norris-Watts, C., \& Levy, P. E. (2004). The mediating role of affective commitment in the relation of the feedback environment to work outcomes. Journal of Vocational Behavior, 65(3), 351-365. https://doi.org/https://doi.org/10.1016/j.jvb.2003.08.003

Osabiya, \& Joseph, B. (2015). The effect of employees motivation on organizational performance. Journal of Public Administration and Policy Research, 7(4), 62-75. https://doi.org/10.5897/JPAPR2014.0300

Porter, L. W., Bigley, G. A., \& Steers, R. M. (2003). Motivation and work behavior (Ed.7). New York: McGraw-Hill.

Ramirez-Solis, E. R., \& Baños-Monroy, V. I. (2015). Between love and war: The effects of affective commitment in organizational politics and organizational performance. The Journal of Organizational Culture, Communications and Conflict, 19(2), 1-28.

Ritz, A. (2009). Public Service Motivation and Organizational Performance in Swiss Federal Government. International Review of Administrative Sciences, 75(1), 53-78. https://doi.org/10.1177/0020852308099506

Seo, M.-G., Bartunek, J. M., \& Barrett, L. F. (2011). The role of affective experience in work motivation: Test of a conceptual model. Journal Organizational Behavior, 31(7), 951-968. https://doi.org/10.1002/job.655

Shamir, B., House, R. J., \& Arthur, M. B. (1993). The Motivational Effects of Charismatic Leadership: A Self-Concept Based Theory. Organization Science, 4(4), 577-594. https://doi.org/https://doi.org/10.1287/orsc.4.4.577

Shea, C., \& Howell, J. M. (1999). Charismatic leadership and task feedback: A laboratory study of their effects on self-efficacy and task performance. The Leadership Quarterly, 10(3), 375396. https://doi.org/https://doi.org/10.1016/S1048-9843(99)00020-X

Siagan, S. P. (2012). Manajemen Stratejik. Jakarta: PT. Bumi Aksara.

Sobandi, B., Sedarmayanti, Utomo, T. W. W., Dawud, J., Nugraha, \& Kusumah, I. B. (2006). Desentralisasi dan tuntutan penataan kelembagaan daerah. Bandung: Humaniora.

Surjadi. (2009). Pengembangan Kinerja Pelayanan Publik. Bandung: Refika Aditama.

Umar, H. (2008). Metode Penelitian untuk Skripsi dan Tesis (Ed. Kedua). Depok: RajaGrafindo Persada.

Vandenberghe, C., Bentein, K., \& Stinglhamber, F. (2004). Affective commitment to the organization, supervisor, and work group: Antecedents and outcomes. Journal of Vocational Behavior, 64(1), 47-71. https://doi.org/https://doi.org/10.1016/S0001-8791(03)00029-0

Wang, E., Chou, H.-W., \& Jiang, J. (2005). The impacts of charismatic leadership style on team cohesiveness and overall performance during ERP implementation. International Journal of Project Management, 23(3), 173-180. https://doi.org/https://doi.org/10.1016/j.ijproman.2004.09.003 


\section{International Journal of Business Management and Economic Review}

Vol. 4, No. 03; 2021

ISSN: 2581-4664

Wang, F.-J., Chich-Jen, S., \& Mei-Ling, T. (2010). Effect of leadership style on organizational performance as viewed from human resource management strategy. African Journal of Business Management, 4(18), 3924-3936.

Wilderom, C. P. M., Berg, P. T. va. den, \& Wiersma, U. J. (2012). A longitudinal study of the effects of charismatic leadership and organizational culture on objective and perceived corporate performance.

The

Leadership

Quarterly,

23(5),

835-848.

https://doi.org/https://doi.org/10.1016/j.leaqua.2012.04.002 